\title{
Adsorption of Flagyl on Prepared Ash from Rice Husk
}

\author{
Haider Abbas and Ammar S. Abbas
}

Chemical Engineering Department, College of Engineering - University of Baghdad, Baghdad, Iraq.

\begin{abstract}
In recent years, it has been evident that searching for alternative methods with low-price and eco-friendly features that produce high-quality adsorbents is in high demand. In the present work, rice husk from Iraqi rice named (Amber) had been used as the primary source to produce rice husk ash (RHA) for the removal of the antibiotic metronidazole (Flagyl) from water. After good drying of rice husk, RHA was obtained at $600{ }^{\circ} \mathrm{C}$ using an electric oven. RHA has been investigated using X-ray diffraction (XRD), porosity, and surface area. The adsorption data of the experimental work were optimized to assess Langmuir and Freundlich's constants. The thermodynamic parameters is likely a change in (Gipp's energy $\left(\Delta \mathrm{G}^{\circ}\right)$, enthalpy $\left(\Delta \mathrm{H}^{\circ}\right)$, and entropy $\left(\Delta \mathrm{S}^{\circ}\right)$ ). The impacts of increasing temperature on adsorption capacity were investigated using variant temperatures $(25,30,45,65)$, and the results revealed that the dynamic adsorption data could be represented by the pseudo-second-order kinetics model. The observed values for the heat of adsorption as well as the free energy were revealed that the adsorption process of Flagyl on RHA favors high temperatures.
\end{abstract}

Keywords: Amber rice, Flagyl, rice husk, adsorption

Received on 08/12/2021, Accepted on 29/12/2021, published on 30/12/2021

https://doi.org/10.31699/IJCPE.2021.4.2

\section{1- Introduction}

Data obtained from recent studies have recognized that drug manufacturing discharges and hospital effluents into the environment bypass the toxic concentrations [1, 2]. Numerous methods have been attempted to specify the types of active pharmaceutical ingredients (APIs) that constitute the highest levels of environmental hazards [3, 4]. One of the essential medications with daily uses during hospitalization is antibiotics [5].

Studies have shown that the release of antibiotics into the waterier ambiance could contribute to the origination of bacteria with antibiotic-resistant genes [6, 7]. Metronidazole is a well-known antibiotic related to the metronidazole class, used to treat infections caused by anaerobic bacteria, and protozoa are among the highest use antibiotics [8].

Metronidazole is accused of resulting in phytotoxicity $[9,10]$. Recently, several methods have been applied to aid in removing or at least minimizing the hazardous effects of such drugs using more economical materials $[11,12]$.

RHA has gained noticeable attention due to its effectiveness and being economically acceptable. [13, 14] As a byproduct, RHA has plentiful uses, such as reinforcing materials, fertilizers, fillers, covering and protecting materials, building material constituents, and as a source of silica owing to its high silica content after combustion (approximately 95\% silica), as shown in Table 1 [15].

\begin{tabular}{ll}
\multicolumn{2}{l}{ Table 1. uses of RHA [15] } \\
\hline The form & Commercial uses \\
\hline As ash & Fertilizer, filler, oil absorbent, covering \\
As a source of silica & agent in steel production, adsorbent \\
As silica chemicals & $\begin{array}{l}\text { Refractory, cement production } \\
\text { Soap, }\end{array}$ \\
$\begin{array}{l}\text { The thermal yield of rice } \\
\text { husk combustion }\end{array}$ & Activated silicon, semi-conductor, etc \\
\hline
\end{tabular}

The draining and rivers of vast quantities of impurities wastes (such as plastics, textile, pharmaceutical industries, etc.) into water has been considered the most critical worldwide problem [16].

Globally, adsorption is one of the different methods experimented with to eliminate medical from wastewater and found to be very effective in terms of simplicity and economically low cost $[17,18]$.

Adsorption is physicochemical processing in which variant types of molecules will depose on a surface [19, 20]. Variant carbons have been obtained from different agricultural and wood wastes, which are widely available and considered environmentally friendly [21-28].

The current study was designed to inspect the preparation and characterization of RHA from Amber rice waste in addition to evaluating the ability of RHA to adsorbed Flagyl (metronidazole) from wastewater.

Corresponding Authors: Name: Haider Abbas, Email: haider_abbas3000@yahoo.com, Name: Ammar S. Abbas, Email: ammarabbas@coeng.uobaghdad.edu.iq 


\section{2- Experimental Work}

\subsection{Preparation and Investigation of RHA} Characterization

The raw materials, the Iraqi rice husk named (Amber) at the beginning were washed several times with (deionized water) distilled water for removing dust, dirt, and other impurities then it all have been removed, but before that, it will be weighted and then drying process had been applied for 6 hours using the dryer at $100{ }^{\circ} \mathrm{C}$ to ensure that any humidity has been removed, dried rice husk was separated to take the weight and placed in diluted acid for 24 hours, After that the drying process was returned to ensure that any humidity has been removed, the resultant had been applied in a furnace at $600{ }^{\circ} \mathrm{C}$ for 6 hours to convert a solid RHA. The RHA properties have been checked by XRD, porosity, and BET surface area.

The prepared RHA was investigated using XRD in the Ministry of Industry, and Minerals, the Chemical and Petrochemical Center. Crystallinity was examined while the pores volume of the RHA, as well as the surface area, were determined using Brunauer-Emmett-Teller (BET) method. The later method was performed using surface area apparatus analyzer-Q surf series.

2.2. Adsorption of Flagyl

A $500 \mathrm{mg} / \mathrm{L}$ (ppm) stock solution of Flagyl was made by dissolving the calculated quantities of Flagyl in deionized water. The study was established using $500 \mathrm{ml}$ conical flasks by mixing a previously weighed amount of Flagyl with the 1-gram of RHA. An agitation has been applied to the solution at $300 \mathrm{rpm}$ with a stirrer at a prespecified temperature for every run $(25,30,40$, and 50 $\left.{ }^{\circ} \mathrm{C}\right)$. After shaking, the mixtures were centrifuged and filtrated. The time interval for reading was (5, $15,25,35,45,60,75,90$, and 420 minutes). The Flagyl concentration was measured at $336 \mathrm{~nm}$ as the absorbance wavelength by UV-VIS apparatus Recording Spectrophotometer (UV-160A) presented in the Chemical Engineering Department, College of Engineering, University of Baghdad.

The adsorption capacity, which refers to the quantity of the adsorbed Flagyl per weight of the adsorbent (rice ash) at equilibrium (qe, $\mathrm{mg} / \mathrm{g}$ ) was computed using Equation (1). The Flagyl removal trend was determined by Equation (2).

$$
q_{e}=\left(C_{o}-C_{e}\right) \times \frac{V}{m}
$$

Flagyl removal, $\%=\frac{C_{o}-C_{t}}{C_{o}} \times 100 \%$

Where $q_{e}$ refers to the capacity of equilibrium adsorption of the adsorbent (in $\mathrm{mg} / \mathrm{g}$ ) while $C_{o}, C_{t}$ and $C_{e}$ in $(\mathrm{mg} / \mathrm{L})$ represent the initial, at any time, and the final concentrations of Flagyl, respectively. V represents the volume of adsorption, which has the unit of $\mathrm{L}$, and $\mathrm{m}$ that has the unit $(\mathrm{g})$ refers to the weight of RHA consumed.

\subsection{Kinetics Models and Adsorption Isotherms}

The concept of adsorption isotherms demonstrates the tendency of interaction that occurs between the adsorbates and adsorbents. The currently used method of twoparameter isotherms was chosen to illustrate the precise amount of the adsorbed Flagyl on the prepared RHA. The adsorption models that were used were Langmuir (Equation (3)) [29] and Freundlich (Equation (4)) [30].

$$
\begin{aligned}
& q_{e}=\frac{q_{\max } K_{L} C_{e}}{1+K_{L} C_{e}} \\
& q_{e}=K_{F} C_{e}^{\frac{1}{n}}
\end{aligned}
$$

Where $q_{e}$ refers to the adsorption capacity (in $\mathrm{mg}$ ) of the adsorbate per each gram of adsorbent, $C_{e}$ is the concentration of Flagyl at equilibrium in $(\mathrm{mg} / \mathrm{L}), q_{\max }$ is the maximum capacity of adsorption to produce a superficial monolayer on the rice ash surface in $(\mathrm{mg} / \mathrm{g})$. $K_{L}$ presents Langmuir coefficient associated with the degree of affinity between the adsorbate and adsorbent in (L/mg), while $K_{F}$ refers to the Freundlich coefficient, and $\mathrm{n}$ refers to the total numbers of multilayers produced.

Two models [31], which are pseudo-first-order (Equation 5), and pseudo-second-order (Equation 6) were performed to show the variation in the capacity of adsorption with time.

$$
\begin{aligned}
& \ln \left(q_{e}-q_{t}\right)=\ln q_{e}-k_{1} t \\
& \frac{t}{q_{t}}=\frac{1}{k_{2} q_{e}}+\frac{t}{q_{e}}
\end{aligned}
$$

Where $q_{e}$, and $q_{t}$ (in $\mathrm{mg} / \mathrm{g}$ ) refer to the capacity of adsorption at equilibrium and at any time (t), respectively. The adsorption rates constant $k_{1}$ in $(1 / \mathrm{min})$ is used for pseudo-first-order, while the adsorption rate constants $k_{2}$ in $(\mathrm{g} / \mathrm{mg}$. $\mathrm{min})$, and $k_{3}$ in $\left(\mathrm{mg} /\left(\mathrm{g} \cdot \mathrm{min}^{0.5}\right)\right)$ are used for pseudo-second order reaction.

By maximizing the correlation coefficient $\left(\mathrm{R}^{2}\right)$, all the observational values of the isothermal and kinetics models were calculated numerically. (Equation (7)) [32].

$R^{2}=\frac{\sum_{i=1}^{n}\left(q_{c a l}-\overline{q_{\text {exp }}}\right)^{2}}{\sum_{i=1}^{n}\left(q_{c a l}-\overline{q_{\text {exp }}}\right)^{2}+\sum_{i=1}^{n}\left(q_{c a l}-q_{\text {exp }}\right)^{2}}$

In Equation (7), $q_{\text {exp }}$ and $q_{\text {cal }}$ (in $\mathrm{mg} / \mathrm{g}$ ) refer to the experimental value and computed value (from the model) of the adsorption capacity, respectively. (i) refers to the current number of the experiment, and $n$ refers to the overall numbers of the performed experiments. 


\subsection{Characterization of Thermodynamic Analysis}

The thermodynamic trend of Flagyl adsorption on the prepared rice husk surface was inspected to calculate thermodynamic parameters during adsorption. The alterations in Gibbs free energy $\left(\Delta G^{\circ}\right.$ enthalpy $\left(\Delta H^{\circ}\right)$ and entropy $\left(\Delta S^{\circ}\right)$ had been computed by conventional thermodynamic equations (Equation (8) and Equation (9)) using the distribution coefficient $\left(\mathrm{K}_{d}\right)$ for determination of adsorption of Flagyl on the surface of the RHA (Equation 10) [23, 33].

$\Delta G=\Delta H-T \Delta S$

$\Delta G=-R T \ln \left(K_{d}\right)$

$\mathrm{K}_{\mathrm{d}}=\frac{q_{e}}{C_{e}}\left(\frac{m}{V}\right)$

In Equation (9), $\mathrm{R}$ implies the gas constant (which is equal to $8.314 \mathrm{~J} / \mathrm{mol} \mathrm{K}$ ), while $\mathrm{T}(\mathrm{K})$ refers to the absolute temperature used during the process of adsorption.

\section{3- Results and discussion}

\subsection{Characterization of RHA}

Analysis of the RHA using X-ray diffractograms was presented in Figure 1. The main peak at angles $\left(2 \theta=22^{\circ}\right.$ refers mainly to silica. However, the measured surface area and pore volume were equal to $148.53 \mathrm{~m}^{2} / \mathrm{g}$ and $0.2540 \mathrm{~cm}^{3} / \mathrm{g}$, respectively.

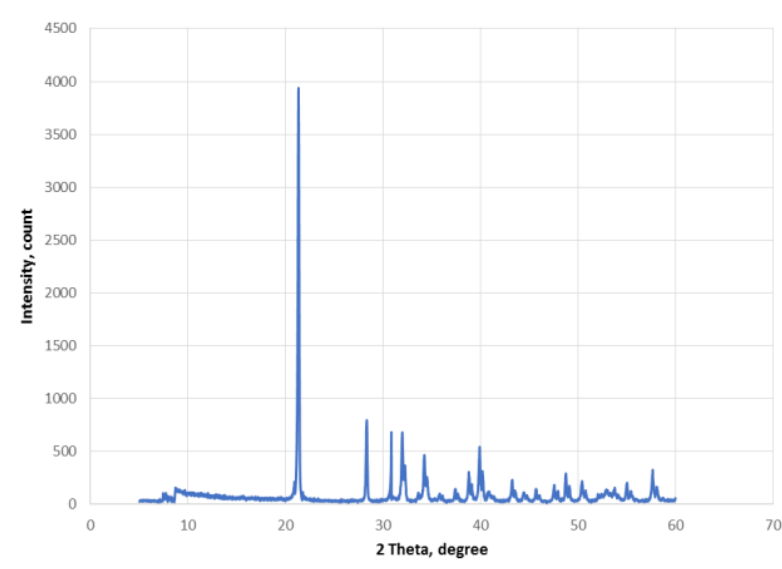

Fig. 1. X-ray diffractogram model of the RHA

\subsection{The Pattern of Adsorption of Flagyl on The RHA}

a. Equilibrium and adsorption isotherms

The Flagyl removal versus different initial concentrations of Flagyl was represented in Table 2. The Flagyl (organics) removal increased with the decreasing of initial concentration.
The increase in the removal values of Flagyl molecules accompanied by the decrease in the initial concentration could be explained by the presence of competition of Flagyl molecules on the most predominant sites of adsorption, which are the pores and the surface of the prepared adsorbents, and this competition decreases when lower Flagyl concentrations were used [34].

Table 2. Flagyl removal versus initial concentrations

\begin{tabular}{ccccccc}
\hline $\mathrm{C}_{\mathrm{o}}, \mathrm{ppm}$ & 503 & 389 & 308 & 207 & 72 & 51 \\
\hline Removal\% & 57.85 & 60.67 & 66.23 & 69.57 & 73.61 & 76.47 \\
\hline
\end{tabular}

Fig. 2 showed the equilibrium adsorption capacity of RHA increased from 39 to $291 \mathrm{mg} / \mathrm{g}$ with an increment in the equilibrium concentrations from $12 \mathrm{ppm}$ (obtained at a lower initial concentration of Flagyl) to $212 \mathrm{ppm}$.

These data were used to solve and obtain via the nonlinear regression analysis, the Langmuir and Freundlich isotherms, and solution results were summarized in Table 3 .

The resultant data revealed that the manufactured rice husk possesses a maximum capacity of adsorption with the amount of Flagyl equal to $588.24 \mathrm{mg}$ for each one gram of the produced rice husk.

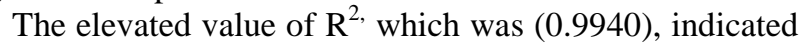
that the Langmuir model best suits the data of the adsorption equilibrium and the Flagyl adsorbed on the RH surface as a monolayer.

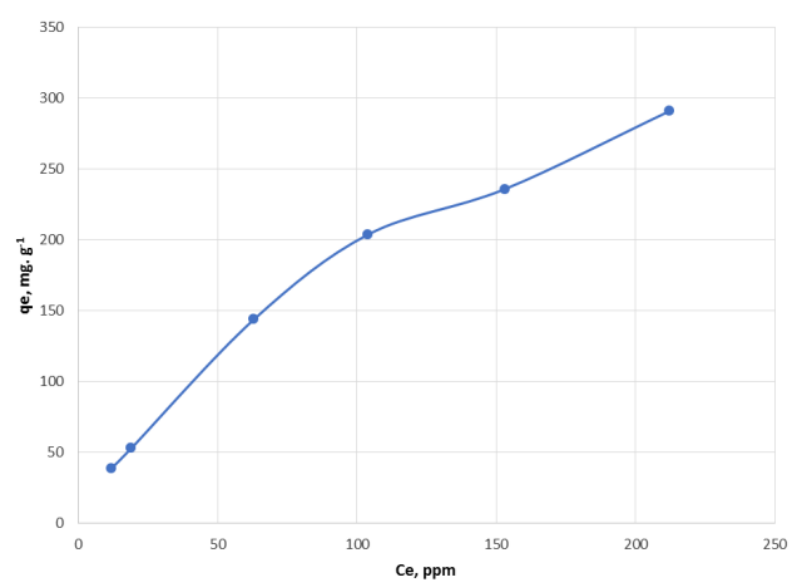

Fig. 2. Flagyl concentration equilibrium effect on the equilibrium capacity of the prepared rice husk

Table 3. Adsorption models constants and the correlation coefficients $\left(\mathrm{R}^{2}\right)$ for the Flagyl removal pattern on the papered rice husk

\begin{tabular}{cccc}
\hline $\begin{array}{c}\text { Isotherm } \\
\text { model }\end{array}$ & parameters & Value of Parameter & $\mathrm{R}^{2}$ \\
\hline Langmuir & $q_{\max }, \mathrm{mg} / \mathrm{g}$ & 588.24 & 0.9940 \\
& $K_{L}, \mathrm{l} / \mathrm{mg}$ & 0.0060 & \\
Freundlich & $K_{F}, \mathrm{mg}^{1-\mathrm{n}} \mathrm{l}^{\mathrm{n}} / \mathrm{g}$ & 1.59 & 0.9577 \\
& $\mathrm{n},-$ & 8.88 & \\
\hline
\end{tabular}


As shown in Figure 3, the removal of Flagyl was raised obviously in the first hour of the experiment because the pores of the prepared rice husk were empty at the beginning. The significant difference in concentrations led to the rapid transfer of Flagyl molecules from liquid bulk to the rice husk surface. In the second period (up to 180 minutes), the removal increased gradually because of the decreasing of Flagyl concentration that caused a decrease in the transfer driving force, and the pores were filled with more Flagyl that adsorbed on the RHA surface, and then competition increasing between Flagyl molecules to find an empty site.

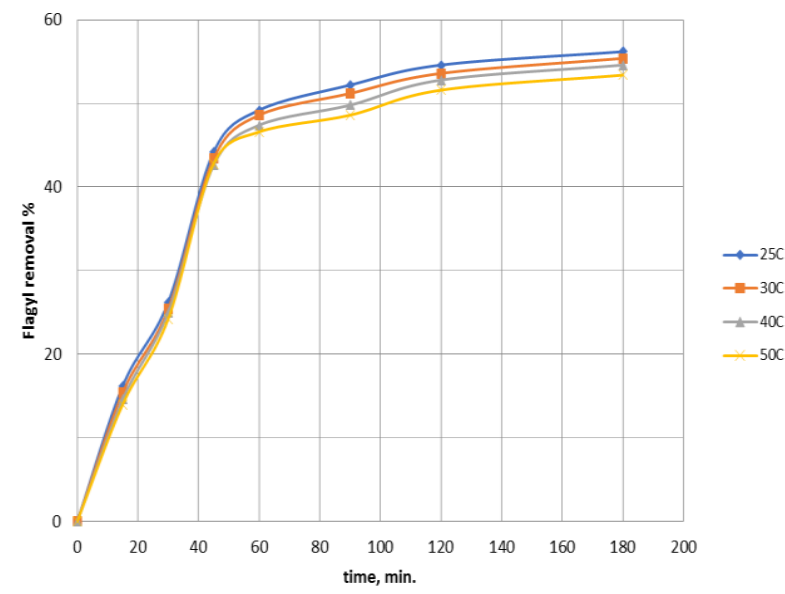

Fig. 3. Relationship between time and the pattern of Flagyl removal via adsorption process on RHA

The kinetic analysis obtained from the adsorption of the Flagyl on the rice husk was summarized in Table 4.

The resulted values of the $\mathrm{R}^{2}$ indicated that the pseudosecond-order model (Equation 6) was well expressed in the data of the experiment.

The $\mathrm{R}^{2}$ data for the pseudo-second-order model ranged from 0.9533 to 0.9658 , which demonstrated a significant and precise description of the resultant data of the experiment with the pseudo-second-order model.

Table 4. Adsorption constants and correlation coefficients $\left(\mathrm{R}^{2}\right)$ for the reduction of COD on the papered rice husk

\begin{tabular}{llllll}
\hline $\begin{array}{l}\text { Adsorption } \\
\text { kinetic } \\
\text { model }\end{array}$ & $\begin{array}{l}\text { Model rate } \\
\text { constant }\end{array}$ & \multicolumn{4}{l}{ Model parameter value at temperature } \\
& $25{ }^{\circ} \mathrm{C}$ & $30{ }^{\circ} \mathrm{C}$ & $40{ }^{\circ} \mathrm{C}$ & $50{ }^{\circ} \mathrm{C}$ \\
\hline & $k_{1},(1 / \mathrm{min})$ & 0.0205 & 0.0168 & 0.0143 & 0.0122 \\
$\begin{array}{l}\text { Pseudo-first } \\
\text { order }\end{array}$ & $q_{e},(\mathrm{mg} / \mathrm{g})$ & 208.0961016 & 193.0791098 & 191.464038 & 185.6754023 \\
& $\mathrm{R}^{2}$ & 0.9397 & 0.8999 & 0.878 & 0.8344 \\
& & & & & \\
& $k_{2}$, & & & & \\
$\begin{array}{l}\text { Pseudo- } \\
\text { second } \\
\text { order }\end{array}$ & & 0.025431426 & 0.02417962 & 0.022988506 & 0.023144453 \\
& $q_{e},(\mathrm{mg} / \mathrm{g})$ & 357.1428571 & 357.1428571 & 357.1428571 & 344.8275862 \\
& $\mathrm{R}^{2}$ & 0.9658 & 0.9614 & 0.9596 & 0.9533
\end{tabular}

Table 5 showed that the thermodynamic process of Flagyl removal had a positive value of $\Delta \mathrm{H}$ (equal 1827.3 $\mathrm{J} / \mathrm{mol}$ ) which means that the Flagyl adsorption increases as the temperature of the experiment decrease.
Additionally, the increasing values of $\Delta \mathrm{G}$ with the temperatures imply that the adsorption favored a reduction in temperatures.

Furthermore, the resultant observations of negative values $\Delta \mathrm{G}$ with the positive value of $\Delta \mathrm{S}$ (which is equal to $8.70 \mathrm{~J} / \mathrm{mol} \mathrm{K}$ ) refer to the spontaneous adsorption of Flagyl molecules on the prepared RHA.

Table 5. Adsorption thermodynamic parameters and correlation coefficients $\left(\mathrm{R}^{2}\right)$ for the reduction of COD on the papered rice husk

\begin{tabular}{cccccc}
\hline $\begin{array}{c}\text { Temperature, } \\
{ }^{\circ} \mathrm{C}(\mathrm{K})\end{array}$ & $\mathrm{K}_{\mathrm{d}}$ & \multicolumn{3}{c}{ Thermodynamic parameters } & \multirow{2}{*}{$\mathrm{R}^{2}$} \\
\cline { 3 - 5 } & & $\Delta G$, & $\Delta H$, & $\Delta S$, & \\
25 & & $\mathrm{~J} / \mathrm{mol}$ & $\mathrm{J} / \mathrm{mol}$ & $\mathrm{J} / \mathrm{mol} \mathrm{K}$ & \\
30 & 1.358 & -759.1 & 1827.3 & 8.70 & 0.9944 \\
40 & 1.381 & -813.1 & & & \\
50 & 1.415 & -904.2 & & & \\
\hline
\end{tabular}

\section{4- Conclusion}

In the recent few decades, there has been a big deal of attention to produce adsorbents characterized by high adsorption capacity while minimizing the cost of the production and impurities associated with the production process. The present work inspected the efficiency of RHA as an adsorbent to remove metronidazole (Flagyl) molecules. The current study results revealed that the percent of removal of Flagyl was inversely proportional to their initial concentrations, i.e., the percent of removal of Flagyl increased as the initial concentration was decreased. Additionally, RHA equilibrium adsorption capacity was directly proportional to the equilibrium concentration. Moreover, the removal of Flagyl molecules was significantly rapid in the first hour of the adsorption process. The adsorption process occurred due to the emptiness of the RHA surface, leading to a less competition effect than the second period of the process when the concentration of Flagyl was gradually increased. Furthermore, the thermodynamic analysis results indicated the inverse relationship between the temperature of the process and the adsorption capacity, with the positive value of $\Delta \mathrm{H}(1827.3 \mathrm{~J} / \mathrm{mol})$.

\section{References}

[1] Escher BI, Baumgartner R, Koller M, Treyer K, Lienert J, McArdell CS. Environmental toxicology and risk assessment of pharmaceuticals from hospital wastewater. Water research. 2011 Jan 1;45(1):75-92.

[2] Larsson DJ. Pollution from drug manufacturing: review and perspectives. Phil. Trans. R. Soc. B. 2014 Nov 19;369(1656):20130571.

[3] Boxall A. B. New and emerging water pollutants arising from agriculture: 2012.

[4] Sorell TL. Approaches to the development of human health toxicity values for active pharmaceutical ingredients in the environment. The AAPS journal. 2016 Jan 1;18(1):92-101. 
[5] Lien LT, Hoa NQ, Chuc NT, et al. Antibiotics in Wastewater of a Rural and an Urban Hospital before and after Wastewater Treatment, and the Relationship with Antibiotic Use-A One Year Study from Vietnam. Int J Environ Res Public Health. 2016;13(6):588. Published 2016 Jun 14. doi:10.3390/ijerph13060588.

[6] Shakti Rath, bydute kumar Dispersal of Antibiotic Resistant Bacteria into Aquatic Environment - An \begin{tabular}{llll}
\hline Overview. & iMedPub & Journals. & 2018.
\end{tabular} Published:February 07, 2018. Vol.1 No.1:2.

[7] Rodriguez-Mozaz S, Chamorro S, Marti E, Huerta B, Gros M, Sànchez-Melsió A, Borrego CM, Barceló D, Balcázar JL. Occurrence of antibiotics and antibiotic resistance genes in hospital and urban wastewaters and their impact on the receiving river. Water research. 2015 Feb 1;69:234-42.

[8] Metronidazole: MedlinePlus Drug Information. Available at https://medlineplus.gov > Drugs, Herbs and Supplements

[9] Pharmaceutical Wastewater Effluent-Source of Contaminants of Emerging Concern: Phytotoxicity of Metronidazole to Soybean (Glycine max). Toxics. 2017;5(2):10. Published 2017 Apr 2. doi:10.3390/toxics5020010.

[10] metronidazole:Topics by Science.gov Retrieved from

https://www.science.gov/topicpages $/ \mathrm{m} /$ metronidazole

[11] Shraim A, Diab A, Alsuhaimi A, Niazy E, Metwally M, Amad M, Sioud S, Dawoud A. Analysis of some pharmaceuticals in municipal wastewater of Almadinah Almunawarah. Arabian Journal of Chemistry. 2017 Feb 1;10:S719-29.

[12] Nasseh I, Khodadadi M, Khosravi R, Beirami A, Nasseh N. Metronidazole Removal Methods from Aquatic Media: A Systematic Review. Annals of Military and Health Sciences Research. 2016;14(4).

[13] Ahmaruzzaman M, Gupta VK. Rice husk and its ash as low-cost adsorbents in water and wastewater treatment. Industrial \& Engineering Chemistry Research. 2011 Nov 23;50(24):13589-613.

[14] Foo KY, Hameed BH. Utilization of rice husk ash as novel adsorbent: a judicious recycling of the colloidal agricultural waste. Advances in colloid and interface science. 2009 Nov 30;152(1-2):39-47.

[15] Production of high quality rice husk ashGreenwich Academic literature archive (GALA). Retrieved from http://gala.gre.ac.uk/12130

[16] Mulugeta M, Lelisa B. Removal of methylene blue $(\mathrm{Mb})$ dye from aqueous solution by bioadsorption onto untreated Parthenium hystrophorous weed. Modern Chemistry \& Applications. 2014 Dec 30.

[17] S. Mondal, "Methods of dye removal from dye house effluent-an overview," Environmental Engineering Science, vol. 25, no. 3, pp. 383-396, 2008.

[18] Mohammed MA, Shitu A, Ibrahim A. Removal of methylene blue using low cost adsorbent: a review. Research Journal of Chemical Sciences ISSN. 2014;2231:606X.
[19] Ghorai S, Sarkar A, Raoufi M, Panda AB, Schönherr H, Pal S. Enhanced removal of methylene blue and methyl violet dyes from aqueous solution using a nanocomposite of hydrolyzed polyacrylamide grafted xanthan gum and incorporated nanosilica. ACS applied materials \& interfaces. 2014 Mar 21;6(7):4766-77.

[20] G. Crini, "Non-conventional low-cost adsorbents for dye removal: a review," Bioresource Technology, vol. 97, no. 9, pp. 1061-1085, 2006.

[21] Khamparia S, Jaspal D, Malviya A. Optimization of adsorption process for removal of sulphonated di azo textile dye. Green Chemistry \& Technology Letters. 2015 Nov 19;1(01):61-6.

[22] Barno, Suondos KA, and Ammar S. Abbas. "Reduction of Organics in Dairy Wastewater by Adsorption on a Prepared Charcoal from Iraqi Sugarcane." In IOP Conference Series: Materials Science and Engineering, vol. 736, no. 2, p. 022096. IOP Publishing, 2020.

[23] A. R. Tehrani-Bagha, H. Nikkar, N. M. Mahmoodi, M. Markazi, and F. M. Menger, "The sorption of cationic dyes onto kaolin: kinetic, isotherm and thermodynamic studies," Desalination, vol. 266, no. 1-3, pp. 274-280, 2011.

[24] Barno, Suondos KA, Haider J. Mohamed, Siham M. Saeed, Mohammed J. Al-Ani, and Ammar S. Abbas. "Prepared 13X Zeolite as a Promising Adsorbent for the Removal of Brilliant Blue Dye from Wastewater." Iraqi Journal of Chemical and Petroleum Engineering 22, no. 2 (2021): 1-6.

[25] A. S. Abbas and S. A. Hussien, "Equilibrium, Kinetic and Thermodynamic Study of Aniline Adsorption over Prepared ZSM-5 Zeolite," Iraqi J. Chem. Pet. Eng., vol. 18, no. 1, pp. 47-56, 2017.

[26] R. K. Abid and A. S. Abbas, "Adsorption of organic pollutants from real refinery wastewater on prepared cross-linked starch by epichlorohydrin," Data Br., vol. 19, pp. 1318-1326, 2018, doi: 10.1016/j.dib.2018.05.060.

[27] F. K. Al-Jubory, I. M. Mujtaba, and A. S. Abbas, "Preparation and Characterization of Biodegradable Crosslinked Starch Ester as Adsorbent," in 2nd International Conference on Materials Engineering \& Science (IConMEAS 2019), 2020, pp. 20165-20169, doi: https://doi.org/10.1063/5.0000170.

[28] Al-Jubory, F. K., I. M. Mujtaba, and A. S. Abbas. "Removal of Ciprofloxacin from Aqueous Solution Using Prepared Biodegradable Potato Crosslinked Starch Ester." In IOP Conference Series: Materials Science and Engineering, vol. 1076, no. 1, p. 012031. IOP Publishing, 2021.

[29] I. Langmuir, "THE CONSTITUTION AND FUNDAMENTAL PROPERTIES OF SOLIDS AND LIQUIDS. PART I. SOLIDS.," J. Am. Chem. Soc., vol. 38, no. 11, pp. 2221-2295, Nov. 1916.

[30] H. M. F. Freundlich, "Uber Die Adsorption in Losungen," Zeitschrift fur Phys. Chemie-Leipzig, vol. 57A, pp. 385-470, 1906. 
[31] K. L. Tan and B. H. Hameed, "Insight into the adsorption kinetics models for the removal of contaminants from aqueous solutions," J. Taiwan Inst. Chem. Eng., vol. 74, pp. 25-48, 2017.

[32] D. C. Montgomery, E. A. Peck, and G. G. Vining, Introduction to linear regression analysis. Wiley, 2012.

[33] B. Samiey and S. Farhadi, "Kinetics and thermodynamics of adsorption of Fuchsin acid on nickel oxide nanoparticles.," Acta Chim. Slov., vol. 60, no. 4, pp. 763-73, 2013.

[34] L. Khenniche and F. Benissad-Aissani, "Adsorptive Removal of phenol by Coffee Residue Activated Carbon and Commercial Activated Carbon: Equilibrium, Kinetics, and Thermodynamics," J. Chem. Eng. Data, vol. 55, no. 11, pp. 4677-4686, Nov. 2010. 


\section{امتزاز الفلاجيل على سطح الرماد المحضر من قثور الرز}

حيدر عباس و عمارصالح عباس

جامعة بغداد/كلبة العندسة

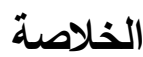

مؤخرا أصبح من الواضح البحث عن الطرق الرخيصة والصديقة للبيئة في عمل البحوث والسعي للحصول

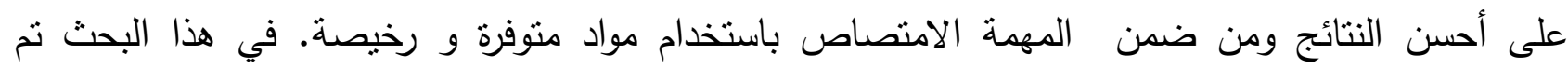

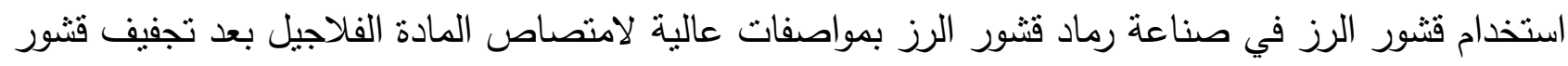

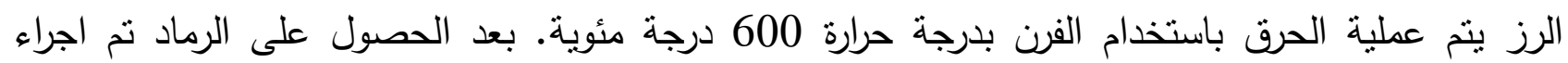

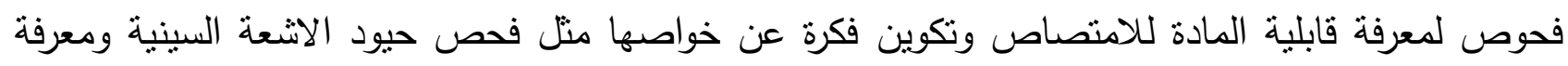

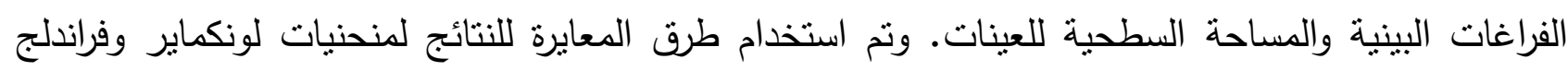

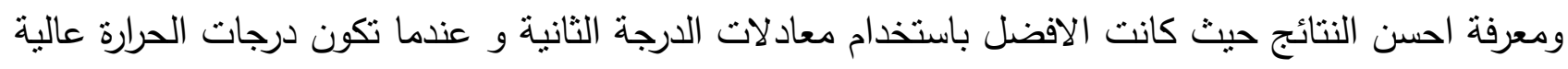

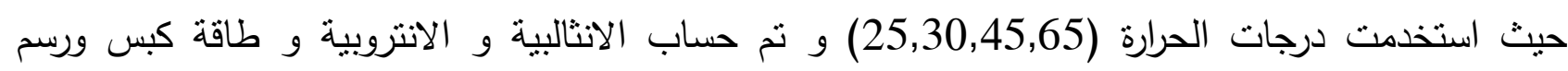
العلاقات لتوضيح فعالية المادة في الامتصاص. الكلمات الدالة: رز العنبر، فلاجيل، قشر الرز، الامتزاز 